\title{
The Exploration and Innovation of E- Marketing Curriculum Reform Model Based on TOPCARES-CDIO Philosophy
}

\author{
Xiu Tang, Yanqi Wang, Guangning Pu \\ Chengdu Neusoft University, Chengdu, China
}

Keywords: E-Marketing, TOPCARES-CDIO, Competition teaching integration.

\begin{abstract}
This research is based on enterprises' needs for personnel in the major of Electronic Commerce under "Internet+" environment, combined with standards and requirements for the talent training scheme, and the cultivation of students' ability for E-commerce enterprise to design lessons. The curriculum design is also based on CDIO (Conceive, Design, Implement, Operation) mode of cultivating talents, and built with characteristic of Chengdu Neusoft Institute's TOPCARES - CDIO "eight ability index system. The key point of this article is to represent how to drive the learning motivation of students through the process of E-marketing competition teaching methods combined with traditional teaching methods, by giving the actual task-driven project to track and give feedback during the teaching, as well as integrating TOPCARES-CDIO education philosophy into the EMarketing course teaching.
\end{abstract}

\section{Introduction}

According to the 40th Statistical Report on the Internet Development in China by the China Internet Network Information Center (CNNIC), as of June 2017, the number of netizens in China reached to 751 million, accounting for one fifth of the total number of Internet users in the world. Internet penetration rate was $54.3 \%$, surpassing the global average of 4.6 percentage points. As the development of the digital technology, the Internet as the example, is speeding up its in-depth integration with various fields of economy and society and has become an important driving force for promoting the upgrading of consumption, economic and social restructuring and building a new competitive edge in our country. The "2017 Spring Internet Talent Trends Report" shows that in recent years, the demand for corporate e-commerce talent in China has been booming. However, the employment ratio of e-commerce graduates is less than $20 \%$. It is difficult for a large number of enterprises to recruit qualified e-commerce professionals. $65 \%$ of the companies think that the lack of quantity and quality shortcomings of industry professionals are the most common problems to be solved urgently.

Strong demand for e-commerce personnel training put forward higher requirements, but the employment rate is lower than other majors. Some graduates also went to training institutions to "relearn" the knowledge. To a certain extent, it reflects that the supply of graduates is booming, but it is difficult for companies to recruit. The reason is that on the one hand, the e-commerce major is a typical practice leading professional, it requires that colleges and universities should pay attention to students' ability training and ability transformation, to adapt to and match the needs of enterprises; the other hand, nowadays companies pay more attention on candidates' professionalism, teamwork, communication and coordination, innovation and creative thinking. Therefore, it is very important to cultivate a comprehensive quality of e-commerce talent. At first, it requires the course to have clear goals of talents cultivation, and detailed description to a specific ability index. Then, it has to ground the ability index into the course syllabus, as well as implementing projects to the course design in every module. At last, it has to make sure students' basic e-commerce knowledge and the application of conversion is the key of the education reform and optimization direction.

\section{Current Teaching Status of E-Marketing}

"E-Marketing" is a core course of e-commerce major. The course integrates Internet technology, new media technology, marketing planning ability and so on, and puts forward higher requirements 
on the students' skills. The course mainly cultivates students to use various Internet tools and EMarketing methods for network planning and promotion, and to achieve corporate's goals to enhance brand image, increase network flow and conversion rate. E-Marketing course itself belongs to highly practical discipline, however, the majority of teaching in colleges and universities mainly focus on the theory teaching, but not practice teaching -- substantive operational ability training. There are few studies on the case contents of the current application of E-Marketing, and most of them are lagging behind in old age and poor in students' perception of substitution; the students' participation rate is not high. Their teaching objective emphasizes on the understanding of basic theory and the memory of basic concepts, and ignores the training of students' operational skills, and further disconnects the contents of E-Marketing from the actual job requirements. Some colleges and universities in the EMarketing process introduced the simulation practice platform, the lack of a real competitive business environment, is not conducive to students in the application process to understand the real business projects.

\section{The Combination of TOPCARES-CDIO Teaching Philosophy and Competition and Teaching Integration}

\subsection{TOPCARES-CDIO Integrated Curriculum System}

TOPCARES - CDIO ability index system contains eight primary index (table 1), 32 secondary indicators and 110 tertiary indicators. With eight ability training as the guide, it promotes the transformation of talent cultivating ability and teaching effect as the goal, established from the training objectives to the mapping of the curriculum system, from the objective to the mapping of the teaching goal, the knowledge elements from three aspects as knowledge, ability and quality to construct the target of profession fostering, established from various professional training objectives to the mapping of the curriculum system, the knowledge from the objective to each unit the teaching goal of mapping, and designs highly integrated, highly associated with the project, the construction from five to level 1 project, escalate the integration course system. Besides focusing on the indicators of knowledge skills, it focuses on developing communication skills, emphasizing the openness and innovation of student thinking, focusing on student values, responsibility, attitude and habits. Through "learning in practice " and " practice in learning " approach, the project-oriented emphasis on the transformation and the transformation and consolidation of knowledge to ability, in line with business needs in the employing capacity, implementation of teaching through the principle of integrated teaching organization, reflects the concept, design, Implementation, operation (CDIO) of the whole process (see Figure 1).

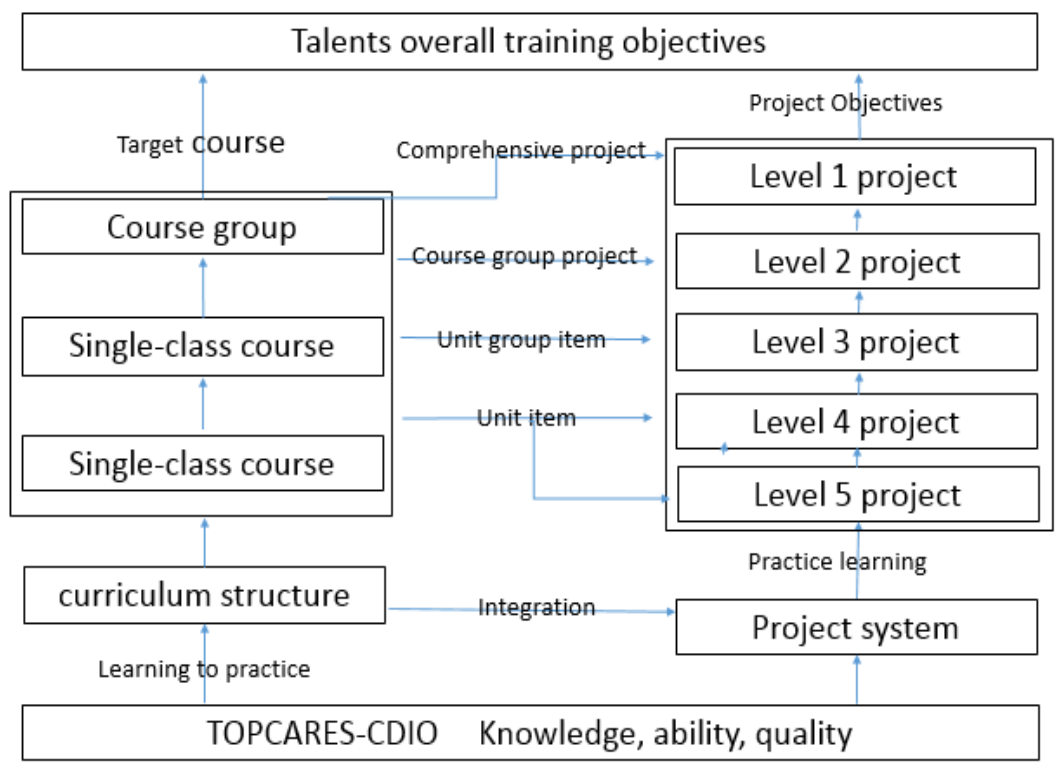

Figure 1 TOPCARES-CDIO integrated curriculum system 
Table 1 TOPCARES-CDIO a capacity index system table

\begin{tabular}{|c|c|c|}
\hline Serial number & abbreviation & Competency indicators \\
\hline 1 & T & Technical knowledge and reasoning \\
\hline 2 & O & Open thinking and innovation \\
\hline 3 & P & Personal and professional skills \\
\hline 4 & C & Communication and teamwork \\
\hline 5 & A & Attitude and manner \\
\hline 6 & R & Responsibility \\
\hline 7 & E & Ethical values \\
\hline 8 & S & Social contribution by application practice \\
\hline
\end{tabular}

\subsection{The Teaching Model of Competition and Teaching Integration}

The course "E-Marketing" emphasizes applicability and practical ability. The characteristics of the course are closely integrated with the events of the current era. The characteristics of the course are closely integrated with the events of the current era. The updating of knowledge is fast and requires the market to react quickly, with diversified methods, application-oriented and result-oriented.

This requires teachers to continuously improve students' ability to innovate and practice. The combination of competition and teaching will, in the opposite direction, require teachers to contact practical projects, focus on hands-on training and training, expeditiously tap the cases and training modules of business and competition needs iteration and optimization courses. At the same time, it puts forward requirements for students' hands-on operation, teamwork, knowledge sharing, systematic thinking and operation layout.

There are many related competitions in E-Marketing, which are divided into industry level and national level as well as various associations and chamber competitions. The selection of a combination of teaching sessions must have the following characteristics: 1 . It has a complete target process and schedule rules, not a new event, reference data from past matches can be evaluated. 2 . Matches' module training and "E-Marketing" teaching ability indicators have to meet the requirements. It has to be maneuverable, and should have a more complete and reasonable evaluation criteria. 3. The schedule of competition events should be in sync with the daily teaching. In that way, it is easy to maintain the theory teaching and practice teaching integration, and can avoid disjunction. Based on the above criteria, a most suitable way was found for a wide range of competitions such as: "E-Marketing Skills", the schedule for 3 months, basically synchronized with the course teaching. Module fit is also relatively high.

\section{Project Design and Implementation Based on TOPCARES-CDIO Competition and Teaching}

\subsection{The Course Design of "E-Marketing" Based on TOPCARES-CDIO Concept}

"E-Marketing" course is targeted for e-commerce undergraduate students, is the core of the backbone of this major. The course focuses on E-Marketing activities and its regularity. It is an applied science which is based on comprehensive contents such as economic science, behavioral science, communication science, consumer psychology and computer application technology, comprehensive strength and high practicality. The previous courses include "introduction to ecommerce", "website design basis" and "marketing".

In the process of curriculum goal setting, based on the enterprise's requirement of professional employment and the development of industry's actual talent output standard, according to the ability index of professional training program, sort out the orientation and function of curriculum in training program and the curriculum TOPCARES-CDIO indicator reflected by the characteristics. Fully extract the

ability of the curriculum objectives, to make it fully meet the requirements of E-Marketing jobs, embodies the professional standards of curriculum development, highlighting the principle of competence, practical principle. Highlight the training of students' comprehensive abilities and 
practical skills, clarify the teaching unit of knowledge and unit (group) project, project the modules of knowledge and skills required by practical hands-on and the parts used by the tools to project, and reasonably plan the teaching time.

After clarifying Knowledge module and project module, with the guidance of eight major capabilities of TOPCARES-CDIO, we set up the goal from three aspects of knowledge, ability and quality and establish the mapping from training goal to curriculum system. Curriculum objectives to the teaching objectives of the unit of knowledge mapping, the completion of TOPCARES-CDIO a goal to the decomposition of three goals, extract the specific capacity and set the weight of training. As shown in Table 2, the content of the course and the contents of the unit group items are set corresponding to the three-level objectives, and the important, general, and not important ones are used in the evaluation indexes. E, M and L are indicated (As shown in Table 3).

Table 2 TOPCARES-CDIO-based target decomposition and capacity of three indicators of weight setting

\begin{tabular}{|c|c|c|c|}
\hline $\begin{array}{l}\text { TOPCARES-CDIO } \\
\text { Primary index }\end{array}$ & $\begin{array}{l}\text { TOPCARES-CDIO } \\
\text { secondary index }\end{array}$ & $\begin{array}{l}\text { TOPCARES-CDIO } \\
\text { tertiary index }\end{array}$ & $\begin{array}{c}\text { Ability } \\
\text { indicator } \\
\text { weight }\end{array}$ \\
\hline \multirow[b]{2}{*}{$\begin{array}{l}\text { 1.Technical knowledge and } \\
\text { reasoning }\end{array}$} & 1.2 basic knowledge & 1.2.1professional knowledge & 7 \\
\hline & $\begin{array}{l}\text { 1.3professional } \\
\text { knowledge }\end{array}$ & 1.3.1professional knowledge & 16 \\
\hline 2.Open thinking and innovation & 2.4innovation ability & $\begin{array}{l}\text { 2.4.1introduce, digest and absorb } \\
\text { re-innovation ability }\end{array}$ & 10 \\
\hline \multirow{3}{*}{ 4.Communication and teamwork } & \multirow{3}{*}{$\begin{array}{l}\text { 4.1communication } \\
\text { ability }\end{array}$} & 4.1 .3 written communication & 11 \\
\hline & & $\begin{array}{l}\text { 4.1.4electronic and multimedia } \\
\text { communication }\end{array}$ & 15 \\
\hline & & $\begin{array}{c}\text { 4.1.6verbal and interpersonal } \\
\text { communication }\end{array}$ & 4 \\
\hline \multirow{3}{*}{$\begin{array}{l}\text { 8. Social contribution by application } \\
\text { practice(CDIO) }\end{array}$} & \multirow{2}{*}{ 8.4business skills } & 8.4.3information management & 13 \\
\hline & & 8.4.4marketing management & 13 \\
\hline & 8.8to implement & $\begin{array}{l}\text { 8.8.1design and implementation } \\
\text { process }\end{array}$ & 11 \\
\hline
\end{tabular}

Table 3 training objectives and course content mapping map

\begin{tabular}{|c|c|c|c|c|c|c|c|c|c|}
\hline Category & $\mathrm{CU}(\mathbf{1})$ & $\mathrm{CU}(2)$ & $\mathrm{CU}(3)$ & $\mathbf{C U}(4)$ & $\mathbf{C U}(5)$ & $\mathbf{U P}(\mathbf{1})$ & $\mathbf{U P}(2)$ & $\mathbf{U P}(3)$ & $\mathrm{CP}(1)$ \\
\hline $\begin{array}{l}\text { TOPCARES-CDIO } \\
\text { tertiary index }\end{array}$ & $\begin{array}{l}\text { E-Marketing } \\
\text { guide }\end{array}$ & $\begin{array}{l}\text { E-Marketing } \\
\text { market } \\
\text { positioning }\end{array}$ & $\begin{array}{l}\text { E-Marketing } \\
\text { platform } \\
\text { construction }\end{array}$ & $\begin{array}{l}\text { Internet } \\
\text { products } \\
\text { online } \\
\text { promotion } \\
\end{array}$ & $\begin{array}{c}\text { E-Marketing } \\
\text { program } \\
\text { planning and } \\
\text { implementation } \\
\end{array}$ & $\begin{array}{l}\text { E-Marketing } \\
\text { target market } \\
\text { research }\end{array}$ & $\begin{array}{c}\text { Network } \\
\text { Optimization } \\
\text { and } \\
\text { Diagnosis } \\
\end{array}$ & $\begin{array}{c}\text { Blog, } \\
\text { Weibo and } \\
\text { WeChat } \\
\text { promotion } \\
\end{array}$ & $\begin{array}{l}\text { E-Marketing } \\
\text { Questionnaire }\end{array}$ \\
\hline $\begin{array}{c}\text { professional basic } \\
\text { knowledge }\end{array}$ & M & M & & & & M & M & M & M \\
\hline $\begin{array}{c}\text { Professional } \\
\text { knowledge }\end{array}$ & E & E & E & E & E & E & E & E & E \\
\hline $\begin{array}{l}\text { The introduction, } \\
\text { digestion, absorption } \\
\text { and re-innovation } \\
\text { ability }\end{array}$ & & & E & E & E & & M & E & E \\
\hline $\begin{array}{c}\text { Written } \\
\text { communication }\end{array}$ & & E & & E & E & E & M & E & E \\
\hline $\begin{array}{c}\text { Electronic and } \\
\text { multimedia } \\
\text { communication }\end{array}$ & & E & E & E & E & E & E & E & E \\
\hline $\begin{array}{c}\text { Oral expression and } \\
\text { interpersonal } \\
\text { communication } \\
\end{array}$ & & E & & E & E & E & & E & E \\
\hline $\begin{array}{c}\text { Information } \\
\text { Management }\end{array}$ & M & & E & E & E & M & E & E & E \\
\hline $\begin{array}{c}\text { Marketing } \\
\text { Management }\end{array}$ & E & E & & E & $\mathrm{E}$ & E & & E & $\mathrm{E}$ \\
\hline $\begin{array}{c}\text { Design and } \\
\text { Implementation } \\
\text { Process } \\
\end{array}$ & & & E & E & E & & E & E & E \\
\hline Weights & 11 & 19 & 16 & 27 & 27 & 22 & 20 & 29 & 29 \\
\hline Description & Teaching co & and ability & & $\begin{array}{l}\text { fill in th } \\
\text { o represe }\end{array}$ & $\begin{array}{l}\text { esponding form } \\
\text { ere } L \text { is the lov }\end{array}$ & $\begin{array}{l}\text { ity indicators } \\
\text { is the highest }\end{array}$ & he course of $t$ & ng the imp & ce of L, M, E \\
\hline
\end{tabular}

\subsection{TOPCARES-CDIO Based Online Marketing Course Competition and Teaching Design 4.2.1 The Basic Requirement Of "E-Marketing Ability Show"}

Under the sponsorship of the Internet Society of China and hosted by the New Competitive EMarketing Management Consultant, the 2017 Fall Undergraduate E-Marketing Capability Show (No. 
18) aims to foster the core competence of college students in online marketing and lay a foundation for enhancing employment and entrepreneurship. Services in the E-Marketing teaching innovation and research, through a variety of online marketing online learning and practice activities, increase E-Marketing teaching fun and sense of accomplishment.

Time of the event: September 11- December 10, 2017

The concrete activity module is shown in Table 4.

Table 4 e-marketing ability show schedule requirements and module settings

\begin{tabular}{|c|c|c|}
\hline Project & Time plan & Practical summary \\
\hline $\begin{array}{l}\text { Practice 1: E-Marketing } \\
\text { Learning and Practice Resource } \\
\text { Preparation } 1.0 \text { points }\end{array}$ & Start the course. & $\begin{array}{l}\text { Register and learn about the following websites and apps: } \\
\text { (1) E-Marketing ability show } \\
\text { (2) blogs and social networks } \\
\text { (3) Concerned about the ability to show the micro signal (wm23abc) and set } \\
\text { the top. } \\
\text { (4) Knowledge Sharing: Baidu Library, Douban, Know, Baidu know } \\
\text { (5) Questionnaire: Available QQ number login }\end{array}$ \\
\hline $\begin{array}{l}\text { Practice 2: Build a personal } \\
\text { social network source } 0.5 \\
\text { points }\end{array}$ & $\begin{array}{l}\text { September } 11 \\
\text { statistics }\end{array}$ & $\begin{array}{l}\text { Personal Information Source Building Walkthrough: } \\
\text { (1) WeChat public number authentication and basic information setting; } \\
\text { (2) publish a self-introduction content, submit the article URL to the ability to } \\
\text { submit the task; } \\
\text { (3) To Weixin public number home page for personal information sources do } \\
\text { post-promotion preparations. }\end{array}$ \\
\hline $\begin{array}{l}\text { Practice 3: Social networking } \\
\text { construction exercise } 0.8 \text { points }\end{array}$ & $\begin{array}{l}\text { September } 11- \\
\text { November } 30\end{array}$ & $\begin{array}{l}\text { Plus ability to show QQ group, the ability to show each other Xiuyou powder, } \\
\text { microblogging each other powder, add WeChat friends, build micro-channel } \\
\text { group, mutual concern WeChat public number. }\end{array}$ \\
\hline $\begin{array}{l}\text { Practice } 4 \text { : One of the network } \\
\text { content: Basic practice } 1.5 \\
\text { points }\end{array}$ & $\begin{array}{l}\text { September } 15 \text { - } \\
\text { November } 30\end{array}$ & $\begin{array}{l}\text { (1) blog writing and blog marketing: publish qualified blog articles (reasonable } \\
\text { topics, title design, keyword design, content editing, links) and share to } \\
\text { microblogging; } \\
\text { (2) WeChat public number article release and share communication. }\end{array}$ \\
\hline $\begin{array}{l}\text { Practice } 5 \text { : Web content } \\
\text { marketing two: document / } \\
\text { image sharing marketing } 1.0 \\
\text { points }\end{array}$ & $\begin{array}{l}\text { September } 20 \text { - } \\
\text { November } 30\end{array}$ & $\begin{array}{c}\text { (1) to complete a thematic document or e-book, choose to publish to the } \\
\text { knowledge-sharing platform; } \\
\text { (2) after passing the knowledge sharing platform audit, submit it to the ability } \\
\text { show individual background; }\end{array}$ \\
\hline $\begin{array}{l}\text { Practice 6: Cooperate and share } \\
\text { marketing practice } 3 \text { points }\end{array}$ & $\begin{array}{l}\text { September } 27 \text { - } \\
\text { November } 30\end{array}$ & $\begin{array}{c}\text { (1) Weibo Forwarding: authoring and publishing a high-quality microblogging } \\
\text { content, obtaining the forwarding number of times over } 30 \text {, and submitting the } \\
\text { weibo URL. } \\
\text { (2) Encyclopedia Wikipedia Wikipedia WIKI exercises: online marketing } \\
\text { dictionary entry editing and writing. }\end{array}$ \\
\hline $\begin{array}{l}\text { Practice } 7: \text { comprehensive } \\
\text { practice } 1 \text { point }\end{array}$ & $\begin{array}{l}\text { October } 10 \text { - } \\
\text { December } 5\end{array}$ & $\begin{array}{l}\text { (1) online questionnaire design } \\
\text { (2) Questionnaire delivery and recovery } \\
\text { (3) Write a survey analysis report, published in the ability to show the official } \\
\text { website, after approval submitted to the background. }\end{array}$ \\
\hline $\begin{array}{l}\text { Practice } 8 \text { : Practice summary } \\
\text { and improve } 1.2 \text { points }\end{array}$ & $\begin{array}{l}\text { October } 20 \text { - } \\
\text { December } 5\end{array}$ & $\begin{array}{l}\text { Practice writing the final report: analysis of practice effect, and published in } \\
\text { the official website, after examination by submitting to the background. }\end{array}$ \\
\hline $\begin{array}{l}\text { Follow-up optional items: } \\
\text { apply for E-Marketing ability } \\
\text { certificate }\end{array}$ & $\begin{array}{l}\text { November } 25 \text { - } \\
\text { December } 10\end{array}$ & $\begin{array}{l}\text { (1) The supervisor can be used as the recommender, and must obtain the } \\
\text { referee qualification in advance; } \\
\text { (2) the student selected by the background references, language submit to } \\
\text { introduce ourselves, waiting for the referees audit, the audit is complete, } \\
\text { generate a certificate, download a certificate. }\end{array}$ \\
\hline
\end{tabular}

The module design is more emphasis on hands-on ability training and practical operation, subdivision module, the standard is clear, the task is reasonable and the AR value score is introduced, and different AR value weights are set under different score items. Scoring through the system to facilitate real-time follow-up and feedback of teachers to perform the task performance, to explain and evaluate, and to ensure synchronization of student and teacher operations.

\subsubsection{Based on TOPCARES-CDIO "E-Marketing" Course Competition and Teaching Design}

In the teaching design that focuses on students' practical ability training, TOPCARES-CDIO's project design focuses on the design of the unit group project, through the participation of student projects to achieve the corresponding ability to shape. E-Marketing ability show competition mainly 
through the practice of various tasks and the AR module AR value of the weight to carry out practical ability evaluation and guidance. By comparing the weights of the project team and the event practice module, we can find out the competencies of the competencies, the enhanced ability training and the failing ability of the match after the curriculum design is integrated into the competition, which is complemented by the classroom instructional design. Specific as shown in Table5.

Table 5 comparison chart of competition weight and teaching design practice module based on TOPCARES-CDIO concept

\begin{tabular}{|c|c|c|c|c|c|}
\hline $\begin{array}{l}\text { TOPCARES-CDIO } \\
\text { Unit (group) project }\end{array}$ & $\begin{array}{l}\text { Item Unit } \\
\text { Group } \\
\text { Weight }\end{array}$ & project & $\begin{array}{c}\mathbf{A R} \\
\text { value }\end{array}$ & $\begin{array}{c}\text { Event } \\
\text { module } \\
\text { weight }\end{array}$ & $\begin{array}{l}\text { Event and unit group } \\
\text { differences in ability to } \\
\text { cultivate }\end{array}$ \\
\hline \multirow{3}{*}{$\begin{array}{c}\text { UP (2) network } \\
\text { optimization and diagnosis }\end{array}$} & \multirow{3}{*}{20} & $\begin{array}{c}\text { Practice 1: Online Marketing } \\
\text { Learning and Practice Resource } \\
\text { Preparation }\end{array}$ & $\begin{array}{c}1.0 \\
\text { points }\end{array}$ & 10 & \multirow{3}{*}{3} \\
\hline & & $\begin{array}{l}\text { Practice 2: Build a personal social } \\
\text { network information source }\end{array}$ & $\begin{array}{c}0.5 \\
\text { points }\end{array}$ & 5 & \\
\hline & & $\begin{array}{l}\text { Practice 3: social relations network } \\
\text { construction exercise }\end{array}$ & $\begin{array}{c}0.8 \\
\text { points }\end{array}$ & 8 & \\
\hline \multirow{3}{*}{$\begin{array}{l}\text { UP (3) blog, Weibo and } \\
\text { WeChat promotion }\end{array}$} & \multirow{3}{*}{29} & $\begin{array}{l}\text { Practice 4: One of the network } \\
\text { content: basic practice }\end{array}$ & $\begin{array}{c}1.5 \\
\text { points }\end{array}$ & 15 & \multirow{3}{*}{16} \\
\hline & & $\begin{array}{c}\text { Practice 5: Web Content Marketing } \\
\text { II: Document / Picture Sharing } \\
\text { Marketing }\end{array}$ & $\begin{array}{c}1.0 \\
\text { points }\end{array}$ & 10 & \\
\hline & & $\begin{array}{l}\text { Practice 6: Cooperate and share } \\
\text { marketing practice }\end{array}$ & $\begin{array}{c}3 \\
\text { points }\end{array}$ & 30 & \\
\hline & 29 & Practice 7: Comprehensive Practice & 1 point & 10 & -19 \\
\hline \multirow[t]{2}{*}{$\begin{array}{l}\text { UP (1) E-Marketing } \\
\text { Questionnaire }\end{array}$} & & $\begin{array}{l}\text { Practice 8: Practice Summary and } \\
\text { Improvement }\end{array}$ & $\begin{array}{c}1.2 \\
\text { points }\end{array}$ & 12 & 12 \\
\hline & 22 & & & & -22 \\
\hline
\end{tabular}

It can be seen from the above table that after the competition session is merged, we can find the difference is a positive value through the specific module training, which reflects that the students submit the corresponding module prepared by the competition to prepare for the training intensity and requirement of the unit group project, and the difference Greater than 10 indicates the target setting for the unit group project that is outstanding and exceeds expectations in the event's training on the project. When the difference is negative, it shows that the event module settings can not meet the capacity requirements of the unit group in the practice of the plate, the classroom activities need to be designed or extra-curricular project layout to supplement the design of hands-on aspects of the design. From Table 6, Practice 4, Practice 5 and Practice 6 can fully reach the training on the method and skill part of the UP (3) blog, Weibo and WeChat promotion unit project team in the online marketing course. However, about the questionnaire part and the network goal Research part of the need for specific in-depth practical project training.

Therefore, in the curriculum design through the project assessment, the output of the questionnaire comprehensive report to highlight the network target research and network questionnaire training section.

\subsubsection{E-Marking Course Assessment Methods}

This course is a skill-based course, so the course examination should reflect the students' comprehensive utilization ability. Course assessment is the process of assessment plus the final assessment, and process-based assessment led. Focusing on the whole process of students learning this course. Specific assessment design as shown in Table 6. 
Table 6 based on the TOPCARES-CDIO concept of competition and teaching a combination of emarketing course assessment methods

\begin{tabular}{|c|c|c|c|c|c|}
\hline category & exam topic & $\begin{array}{l}\text { Assessment of the main } \\
\text { content }\end{array}$ & Assessment & Exam time & $\begin{array}{l}\text { Share } \\
\text { Weights }\end{array}$ \\
\hline \multirow{5}{*}{$\begin{array}{l}\text { Formative } \\
\text { assessment }\end{array}$} & Usual grades & $\begin{array}{l}\text { Attendance and daily } \\
\text { performance }\end{array}$ & the way & $1-16$ weeks & $10 \%$ \\
\hline & \multirow{3}{*}{ Usually homework } & $\begin{array}{l}\text { E-Marketing target market } \\
\text { research }\end{array}$ & $\begin{array}{c}\text { Process } \\
\text { assessment }\end{array}$ & 2-4 weeks & $5 \%$ \\
\hline & & $\begin{array}{c}\text { Network Optimization and } \\
\text { Diagnosis }\end{array}$ & $\begin{array}{c}\text { Project } \\
\text { evaluation }\end{array}$ & 4-5 weeks & $5 \%$ \\
\hline & & $\begin{array}{c}\text { Blog, Weibo and WeChat } \\
\text { promotion }\end{array}$ & $\begin{array}{c}\text { Project } \\
\text { evaluation }\end{array}$ & $\begin{array}{l}10-13 \\
\text { weeks }\end{array}$ & $10 \%$ \\
\hline & Practice the final grade & $\begin{array}{l}\text { E-Marketing ability to show } \\
\text { individual race results }\end{array}$ & $\begin{array}{c}\text { Project } \\
\text { evaluation }\end{array}$ & $\begin{array}{l}\text { September- } \\
\text { December }\end{array}$ & $20 \%$ \\
\hline $\begin{array}{c}\text { Midterm } \\
\text { examination }\end{array}$ & Practice period results & $\begin{array}{l}\text { E-Marketing promotion period } \\
\text { comprehensive results }\end{array}$ & $\begin{array}{c}\text { Project } \\
\text { evaluation }\end{array}$ & Week 8 & $10 \%$ \\
\hline $\begin{array}{c}\text { Final } \\
\text { assessment }\end{array}$ & Questionnaire & E-Marketing Questionnaire & $\begin{array}{c}\text { Project } \\
\text { evaluation }\end{array}$ & $\begin{array}{l}\text { End of } \\
\text { period }\end{array}$ & $40 \%$ \\
\hline
\end{tabular}

\section{Summary and Inspiration}

TOPCARES-CDIO concept of E-Marketing course design make full use of the task-oriented project, realizing learning from doing, and doing from learning. In addition to master the knowledge of this course, from the add-on three comprehensive hands-on projects, this reformed course strengthen students' understanding of the industry and the network environment, market awareness, investigation of the systematic design, detailed data analysis. It can also get feedback from project assessment.

\section{References}

[1]. N. Chen. 2015. "E-marketing Course Design based on skill competition," Personnel., 12:87-88.

[2]. J. Z. Zha. 2008. "Research on Learning from Doing Strategy under CDIO Mode," Higher Engineering Education, 3:55.

[3]. E. F. Crawley, J. Malmqvist, S. Ostlund, and et al. "Re-understanding on engineering education: the mode and method of international CDIO training," Higher Education Press.

[4]. T. Wen. 2011. "Exploration on Personnel Training Model Based on TOPCARES-CDIO Philosophy", Chinese Higher Education, 7:11-13.

[5]. Y. F. Li, 1990. "Exploration and Considerations on Reform Courses under Flipped-classroom Mode - Using Android Programming Course Design as an Example", Information Construction, 9:78-79. 